\title{
Regional Distribution and Developmental Expression of Epidermal Growth Factor and Transforming Growth Factor- $\alpha$ mRNA in Mouse Brain by a Quantitative Nuclease Protection Assay
}

\author{
Lorraine M. Lazar and Mariann Blum
}

Fishberg Research Center in Neurobiology, Mount Sinai Medical Center, New York, New York 10029

\begin{abstract}
A solution-hybridization ribonuclease-protection assay was used to identify epidermal growth factor (EGF) mRNA in mouse brain and to compare the regional and developmental levels of EGF gene expression in the CNS with those of its structural homolog, transforming growth factor- $\alpha$ (TGF- $\alpha$ ). Adult brain regions examined included brainstem, cerebellum, cerebral cortex, hippocampus, basal hypothalamus, olfactory bulb, olfactory tubercle, striatum, and thalamus. While both EGF and TGF- $\alpha$ mRNAs were detected in all regions, TGF- $\alpha$ mRNA levels were 15-170 times higher, ranging from 0.39 (cerebellum and cerebral cortex) to 2.93 (striatum) pg TGF $-\alpha$ mRNA/ $\mu \mathrm{g}$ total cytoplasmic RNA. In contrast, EGF mRNA levels ranged from 11 to $36 \mathrm{fg}$ EGF mRNA/ $\mu \mathrm{g}$, with the highest regional concentrations observed in olfactory bulb, basal hypothalamus, and cerebellum. In our comparison between sexes, no significant male-female differences in EGF or TGF- $\alpha$ mRNA levels were observed for any region of adult brain. However, in the pituitary gland, consisting of both endocrine and neural elements, EGF and TGF- $\alpha$ mRNA levels were significantly higher in males (234 and $215 \mathrm{fg} / \mu \mathrm{g}$, respectively) than in females (172 and $118 \mathrm{fg} / \mu \mathrm{g}$, respectively). An examination of growth factor gene expression in the developing CNS revealed EGF and TGF- $\alpha$ mRNAs detectable as early as embryonic day 14 (earliest time point studied). While gene expression for both peptides continued into the postnatal period, EGF and TGF- $\alpha$ mRNA levels were nearly equal to adult concentrations by postnatal day 10 . Taken together, our findings provide evidence for the synthesis of EGF in brain and suggest a role for both EGF and TGF- $\alpha$ in the development and support of the mammalian CNS.
\end{abstract}

Epidermal growth factor (EGF) is a potent mitogenic peptide, first isolated from the male mouse submaxillary gland (Cohen, 1962), influencing the growth and development of a variety of tissues (reviewed in Carpenter and Cohen, 1979; Carpenter and

\footnotetext{
Received Aug. 16, 1991; revised Nov. 21, 1991; accepted Nov. 26, 1991

We thank Dr. Ed Gresik for his valuable suggestions and comments during the preparation of the manuscript, Dr. Victor Friedrich for his advice on statistical analysis and descriptions of anatomic procedures, Mr. Boh Woolley for his photography and computer-assisted graphics, and Drs. Eric Lazar and Diana Casper for their critical readings of multiple "final" drafts of the manuscript. This work was supported by Medical Scientist Training Grant GM07280 to L.M.L. and an Irma T. Hirschl Career Scientist Award to M.B.

Correspondence should be addressed to Dr. Mariann Blum, Fishberg Research

Center in Neurobiology, Mount Sinai Medical Center, One Gustave L. Levy Place, New York, NY 10029.

Copyright (C) 1992 Society for Neuroscience $0270-6474 / 92 / 121688-10 \$ 05.00 / 0$
}

Wahl, 1990). From observations in culture, EGF has been shown to promote the proliferation and differentiation of glia (Leutz and Schachner, 1981; Simpson et al., 1982; Honegger and Guentert-Lauber, 1983) and to enhance neuron survival and process outgrowth (Morrison et al., 1987, 1988; Casper et al., 1991). The normal physiologic function of EGF in brain, however, has not been determined despite the presence of EGF receptors (EGF-R) in both the developing and mature CNS (Adamson and Meek, 1984; Chabot et al., 1988; Gómez-Pinilla et al., 1988; Hiramatsu et al., 1988; Werner et al., 1988).

Perhaps one of the greatest obstacles to elucidating roles for EGF in the nervous system has been the inability to establish firmly its presence in the CNS. Indeed, published reports concerning the immunological detection of EGF in brain have remained inconsistent and controversial. The intense EGF immunostaining observed in pallidal and cortical regions of adult rodent brain by Fallon et al. (1984), for example, has not been observed by other investigators employing comparably sensitive and specific immunohistochemical techniques (Poulsen et al., 1986; Beerstecher et al., 1988). Attempts to identify EGF immunologically in extracts of both rodent and human brain have produced conflicting results as well (Byyny et al., 1972; Lakshmanan et al., 1986; Probstmeier and Schachner, 1986; Schaudies et al., 1989). With only one incidental observation of low EGF mRNA levels in whole adult mouse brain (Rall et al,, 1985), no evidence for the expression of EGF mRNA in fetal brain (Carpenter and Wahl, 1990), and the inability of EGF to cross the blood-brain barrier (Nave et al., 1985; Jørgensen et al., 1988), the source of the intense EGF immunostaining observed in the CNS remains unclear.

The apparent discrepancy among these findings has led to speculations that EGF is not endogenously synthesized in brain, but that other peptides sharing EGF-like structural characteristics serve as the physiological ligands for EGF-R activation in the CNS (Probstmeier and Schachner, 1986; Ojeda et al., 1990). Transforming growth factor- $\alpha$ (TGF- $\alpha$ ), a structural homolog of EGF able to compete equally well in EGF-R binding studies (Carpenter et al., 1983; Marquardt et al., 1983, 1984; Massagué, 1983), has been considered the likeliest of such candidates based on relatively strong immunological and molecular evidence supporting its synthesis in both the developing and mature CNS (Lee et al., 1985a; Fallon, 1987; Wilcox and Derynck, 1988; Kudlow et al., 1989; Brown et al., 1990; Fallon et al., 1990; Ojeda et al., 1990). Therefore, whether EGF is expressed in brain in addition to $\mathrm{TGF}-\alpha$ remains unclear.

At present, Rall et al. (1985) provide the only evidence for preproEGF mRNA expression in the CNS, having performed 
dot blot hybridization on RNA isolated from whole adult mouse brain. However, their report acknowledged that some crosshybridization between their probe and other EGF-like mRNA sequences was possible. We have therefore chosen to examine EGF and TGF- $\alpha$ mRNA expression in brain by a ribonuclease protection assay in order to clarify whether EGF mRNA is in fact synthesized in the CNS and, if so, how EGF gene expression in brain might relate to that of its structural homolog TGF- $\alpha$. The advantage of using this technique over other commonly chosen methods (including dot blot and Northern blot hybridizations) is that it affords one the ability to detect and quantitate extremely low levels of mRNA and, further, allows one to distinguish between similar mRNA sequences expressed in the same tissue. Exploiting these methodological advantages, then, our findings on the (1) regional distribution, (2) expression between sexes, and (3) developmental profiles of EGF and TGF- $\alpha$ mRNAs in mouse brain suggest that both EGF-R ligands may play a role in the development and support of the mammalian CNS.

\section{Materials and Methods}

Tissue collection. Anatomically defined brain dissections were performed on 60 male and 30 female adult Swiss-Webster mice (86-88 d) as diagrammatically represented in Figure 1. Individual animals, killed by cervical dislocation, were decapitated, their olfactory tracts transected in situ (corresponding to dissection 1 of Fig. 1), and the remaining intact brain transferred to an ice-cooled glass plate. After dislodging olfactory bulbs and whole pituitary from their bony fossae, transection of the brainstem (midbrain-pons-medulla) was performed at the medullary-spinal junction (dissection 2) and in a plane passing rostral to the superior colliculi and caudal to the mammillary nuclei (dissection 3). Cerebellum was subsequently isolated by severing the cerebellar peduncles (dissection 4). From the ventral surface, dissection of the basal hypothalamus was achieved by surrounding its protruding surface, delineated by the optic tracts, and cutting rostrally to reach the optic chiasm (dissection 5). The cerebral hemispheres, sliced in the midsagittal plane, were subsequently positioned medial surface down, and the olfactory tubercles (outlined by the myelinated lateral olfactory tracts) were skimmed from the cortical surface (dissection 6). Following the dorsolateral contours of the thalamus beneath the fornix (arrow 7), this diencephalic region (consisting primarily of thalamic structures) was detached from laterally bordering fibers of the internal capsule and removed ventromedially with anterior commissure and optic chiasm serving as rostral delimitations (disscction 8 ). The hippocampus, now medially exposed, was removed by elevation of its fimbrial border and subsequent cortical detachment. Dissection of the striatum (caudateputamen-globus pallidus), approached from the medial surface of the hemisected brain through the lateral ventricle, was anatomically defined by encapsulating fibers of the corpus callosum and the internal capsule. With hippocampus and striatum removed, sampling of frontoparietal cortex was permitted. All brain tissues, having been frozen over dry ice upon dissection, were ultimately stored at $-80^{\circ} \mathrm{C}$ until processed for the isolation of total cytoplasmic RNA. Submaxillary gland (SG), serving as an EGF assay control tissue, and anterior pituitary (microscopically dissected from 20 of the male whole pituitaries), providing a TGF- $\alpha$ control, were similarly collected and stored.

For the developmental analysis of growth factor mRNA expression, 12 pregnant Swiss-Webstcr mice wcre commercially obtained with vaginal plug dates reported as embryonic day 1 (E1). At 14, 15, 16, and 17 days of gestation, pairs of female mice were killed by cervical dislocation and their embryos dissected from uteri. Whole embryonic brains were subsequently removed with the aid of a dissecting microscope, frozen on dry ice, and stored at $-80^{\circ} \mathrm{C}$ until processed for RNA isolation. Two neonatal litters each of 1 - and 10-d-old Swiss-Webster pups were obtained [day of birth designated as postnatal day $0(\mathrm{P0})$ ], and following their decapitation, whole brains were collected and frozen.

Isolation of cytoplasmic RNA. Total cytoplasmic RNA was prepared from dissected brain, pituitary, and submaxillary gland tissue as described (Jakubowski and Roberts, 1992). Briefly, individual tissues were removed from $-80^{\circ} \mathrm{C}$ storage, placed into the barrel of a $1 \mathrm{ml}$ tuberculin syringe (serving as a disposable homogenizer), and briefly thawed. Ice-
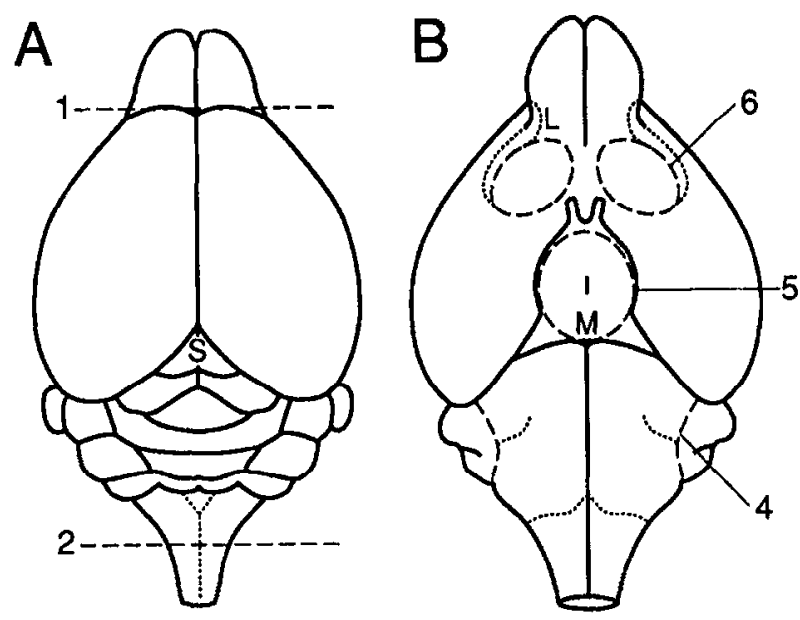

C

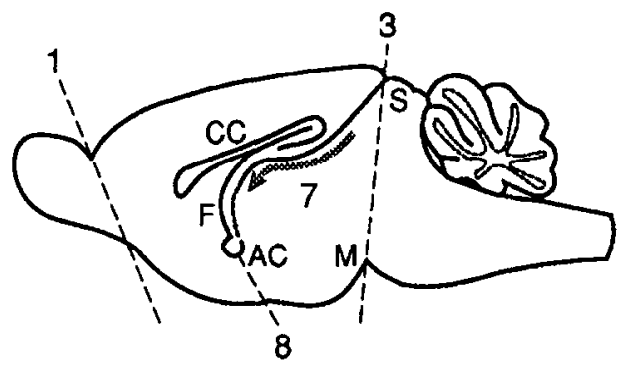

Figure 1. Diagrammatic representation of the regional dissection of adult mouse brain. $A$, dorsal view; $B$, ventral view; $C$, mid-sagittal view. Numbers $1-8$ indicate the positions of cuts sequentially performed during dissection. See Materials and Methods for complete description. Dissection landmarks are abbreviated as follows: $S$, superior colliculi; $L$, lateral olfactory tract; $M$, mammillary nuclei; $C C$, corpus callosum; $F$, fornix; $A C$, anterior commissure.

cold ribonuclease-free lysis buffer $(10 \mathrm{mM}$ Tris- $\mathrm{HCl}, \mathrm{pH} 7.4,1.5 \mathrm{~mm}$ $\mathrm{MgCl}_{2}, 0.5 \%$ Nonidet P-40, $0.25 \%$ sodium deoxycholic acid, $0.3 \mathrm{M}$ sucrose) was subsequently drawn into the syringe through a 22 gauge needle. By repeatedly expelling lysis buffer and tissue through the needle ( $\sim 8-10$ strokes), complete homogenization of tissue without the disruption of nuclei was achieved. A ratio of $\sim 100 \mathrm{mg}$ wet tissue weight per milliliter of lysis buffer was maintained. Lysates were subsequently layered over a sucrose cushion (10 mM Tris- $\mathrm{HCl}$, pH 7.4, $1.5 \mathrm{~mm} \mathrm{MgCl}$, $0.4 \mathrm{M}$ sucrose) and centrifuged $\sim 5000 \times g$ for $10 \mathrm{~min}$ at $4^{\circ} \mathrm{C}$. Supernatants consisting of cyloplasmic fractions were recovered and treated with $0.2 \mathrm{mg} / \mathrm{ml}$ proteinase $\mathrm{K}, 0.03$ vol $5 \mathrm{M} \mathrm{NaCl}$, and 0.1 vol $10 \times \mathrm{SET}$ (1 $\times$ SET: $1 \%$ SDS, 5 mm EDTA, pH 8.0, 10 mm Tris- $\mathrm{HCl}$, pH 8.0) for i hr at $45^{\circ} \mathrm{C}$. Following phenol-chloroform and chloroform extractions, cytoplasmic RNA fractions were precipitated at $-20^{\circ} \mathrm{C}$ with 2 vol 4.5 M sodium acetate, $\mathrm{pH} 7$.

RNA samples to be assayed were recovered by centrifugation at $\sim 16,000 \times \mathrm{g}$ for $20 \mathrm{~min}$ at $4^{\circ} \mathrm{C}$. The resulting pellets were washed with $70 \%$ ice-cold $\left(-20^{\circ} \mathrm{C}\right)$ ethanol, dried, and resuspended in diethylpyrocarbonate-treated deionized water. RNA concentrations were subsequently determined by $A_{260}$ readings. Quantitated samples, prepared from individual animals, were ultimately pooled such that EGF and TGF- $\alpha$ assay samples (40-100 $\mu \mathrm{g}$ and $10-100 \mu \mathrm{g}$, respectively) could be drawn from the same RNA preparations. Agarose gel electrophoresis confirmed that the RNA was undegraded and free of DNA. In order to standardize the total quantity of RNA in all samples of a given assay, total yeast RNA was added where necessary. Aliquoted samples were ultimately dried, resuspended in $30 \mu \mathrm{l}$ of freshly prepared hybridization buffer (80\% formamide, $40 \mathrm{~mm}$ PIPES, pH 6.7, 1 mM EDTA, pH 8.0, $0.4 \mathrm{M} \mathrm{NaCl}$ ) and stored at $-80^{\circ} \mathrm{C}$ until assayed.

Preparation of DNA templates for in vitro transcription of RNA standards and ${ }^{32}$ P-labeled antisense riboprobes. Plasmid pmEGF 344, consisting of a 344 base pair (bp) mouse preproEGF cDNA insert flanked by T3 and T7 RNA polymerase promoters, was constructed by subcloning the $3^{\prime}$ Pstl fragment of clone pmEGF-26F12, kindly provided 
A

\begin{tabular}{r|r|c|c|c|c|c|c|c|}
\hline & \multicolumn{4}{c}{123} & 4 & 567 \\
\hline
\end{tabular}

$\longmapsto$ PMEGF 344

B

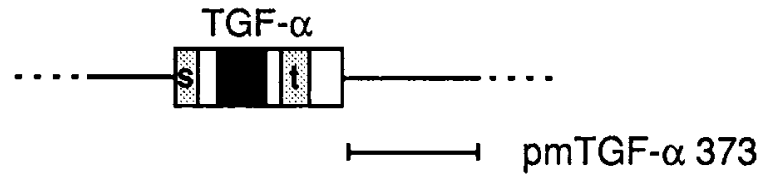

Figure 2. Schematic representation of EGF and TGF- $\alpha$ subclones used to generate RNA probes and standards. $A$, A 344 bp mouse EGF cDNA sequence of plasmid pmEGF 344, shown in reference to the full-length preproEGF mRNA transcript (redrawn from Scott et al., 1983; Doolittle et al., 1984), was used as a template for the in vitro transcription of EGF-specific RNA probes and standards. Defining nucleotides 3023-3366 (Gray et al., 1983) of the preproEGF mRNA, this subclone fragment included sequences encoding the mature EGF peptide (solid box). Numbers 1-7 (Scott et al., 1983) or letters $a-i$ (Doolittle et al., 1984), designated within the preproEGF mRNA transcript, indicate the EGF-like peptide sequences sharing varying degrees of homology with EGF. Untranslated $5^{\prime}$ and 3 ' sequences are represented by lines; the open bar represents the protein-coding portion of the mRNA. Predicted signal sequence and transmembrane domains (shaded regions) are designated $s$ and $t$, respectively. $B$, The TGF- $\alpha$ peptide coding region (solid box), predicted signal and transmembrane domains (shaded areas), and untranslated $5^{\prime}$ and $3^{\prime}$ sequences (extended lines) of the TGF- $\alpha$ mRNA transcript are indicated (redrawn from Lee et al., 1985a). The 373 bp mouse genomic DNA fragment (contained within plasmid $p m T G F-\alpha 373$ ), used in the generation of TGF- $\alpha$-specific RNA probes and standards, defined the most upstream segment in the $3^{\prime}$ untranslated region of the TGF- $\alpha$ mRNA transcript beginning six bases $3^{\prime}$ to the translational stop codon (Wilcox and Derynck, 1988 ).

by Dr. Axel Ullrich (Max-Planck-Institut für Biochemie, Martinsreid), into the PstI site of the Bluescript II/KS(+) vector (Stratagene). As shown in Figure 2A, this cDNA insert (spanning bp 3023-3366; Gray et al., 1983) included nearly the entire coding sequence for the mature EGF peptide. Plasmid pmTGF- $\alpha 373$, similarly constructed with the Bluescript II/KS(+) vector, contained a 373 bp BamHI-AvaI fragment (Fig. $2 B$ ) obtained from the $5^{\prime}$ end of a 1400 bp TGF-agenomic Sau 3AI sequence, generously provided by Dr. Rik Derynck (Wilcox and Derynck, 1988).

In preparation for in vitro transcription reactions, EGF and TGF- $\alpha$ plasmid recombinants were enzymatically restricted either $5^{\prime}$ (for antisense riboprobe) or 3' (for sense RNA standards) to their specific DNA insert sequences, purified by agarose gel electrophoresis, and recovered using the Geneclean DNA isolation technique (Bio 101). ${ }^{32} \mathrm{P}-\mathrm{UTP}-$ labeled antisense riboprobes $\left(1-2 \times 10^{9} \mathrm{cpm} / \mu \mathrm{g}\right)$ or unlabeled RNA standards were subsequently generated by respective T3- or T7-promoted in vitro transcription reactions performed essentially as described (Blum, 1989). Purification of probe or RNA standards from unincorporated nucleotides was achieved by ethanol precipitation at $-20^{\circ} \mathrm{C}$ in the presence of $2.5 \mathrm{M}$ ammonium acetate.

Solution hybridization ribonuclease protection assay. Solution hybridization ribonuclease protection assays were performed as described (Sambrook et al., 1989). RNA standard tubes were prepared with increasing quantities of in vitro synthesized sense-strand RNA and aliquots of total yeast RNA, equalizing the total quantity of RNA in all tubes of a given assay. EGF-specific standards ranged from $50 \mathrm{fg}$ to $4 \mathrm{pg}$, while TGF- $\alpha$ standards ranged from $100 \mathrm{fg}$ to $16 \mathrm{pg}$ (zero tubes contained total yeast RNA only). All standards were in a final volume of $30 \mu l$ hybridization buffer (see above). Following the addition of excess radiolabeled riboprobe $(1 \mu$ of $\sim 100-200 \mathrm{pg} / \mu \mathrm{l})$, samples were heat denatured at $85^{\circ} \mathrm{C}$ for $10 \mathrm{~min}$ and transferred to a $45^{\circ} \mathrm{C}$ water bath for solution hybridization overnight (16-18 hr). Samples were then incubated with $300 \mu \mathrm{l}$ RNase digestion mixture $(40 \mu \mathrm{g} / \mathrm{ml}$ RNase A, $2 \mu \mathrm{g} /$ $\mathrm{ml}$ RNase T1, $10 \mathrm{~mm}$ Tris-HCl, pH 7.5, $5 \mathrm{~mm}$ EDTA, pH 8.0, 300 mM $\mathrm{NaCl})$ for $1 \mathrm{hr}$ at $30^{\circ} \mathrm{C}$, briefly treated with $0.1 \mathrm{mg} / \mathrm{ml}$ proteinase $\mathrm{K}(15$ min at $37^{\circ} \mathrm{C}$ in the presence of $1 \%$ SDS), extracted with phenol-chloroform and ethanol precipitated with the addition of $15 \mu \mathrm{g}$ total yeast RNA. RNA:RNA hybrid pellets were recovered by centrifugation, washed with $70 \%$ ethanol, dried, resuspended in $7 \mu \mathrm{l}$ gel-loading buffer, and analyzed on a $4 \%$ nondenaturing acrylamide gel. After drying and exposing the gel to $x$-ray film, full-length protected gel bands were cut out and quantitated by liquid scintillation counting. Using regression lines generated by plotting known amounts of RNA standards against the observed cpm in their protected bands, sample cpm values were transformed to mass quantities. A mathematical correction was made to account for the slight difference in length between RNA standards (pos- sessing short hybridizing spans of vector sequences) and the protected length of sample hybrids. Values were ultimately adjusted to reflect the levels of full-length mRNA [ $4900 \mathrm{bp}$ for mouse preproEGF (Rall et al., 1985 ) and $5000 \mathrm{bp}$ for mouse TGF- $\alpha$ (Wilcox and Derynck, 1988)].

\section{Results}

Detection of EGF- and TGF- $\alpha$-specific $m R N A s$

Solution hybridization ribonuclease protection assays were developed for the detection and quantitation of EGF and TGF- $\alpha$ mRNA in mouse tissue. Representative autoradiographs demonstrating protected hybrids of EGF and TGF- $\alpha$ RNA are shown in Figure 3. The span of EGF-specific standards, ranging from $50 \mathrm{fg}$ to $4 \mathrm{pg}$ RNA, was determined such that the levels present in cytoplasmic RNA extracts fell between the lowest and highest nonzero standard values. Similarly, a typical TGF- $\alpha$ RNA standard curve, covering a range of values from $100 \mathrm{fg}$ to $16 \mathrm{pg}$, was chosen so that all detected levels were within this defined range. Linear regression correlation coefficients $\left(r^{2}\right)$ of all assay standard curves were $\geq 0.990$.

Adult male SG RNA, employed as a positive EGF mRNA assay control (Rall et al., 1985), was observed to protect the antisense EGF RNA probe (Fig. 3, upper left), providing the complementary (sense) EGF mRNA required for full-length hybrid formation and ribonuclease resistance. Similarly, cytoplasmic RNA isolated from the anterior lobe of adult pituitary, known to express TGF- $\alpha$ and its mRNA (Kobrin et al., 1986, 1987; Samsoondar et al., 1986; Borgundvaag et al., 1990), was observed to protect the antisense TGF- $\alpha$ RNA probe (Fig. 3, upper right) and was subsequently used as a positive TGF- $\alpha$ mRNA control.

Total yeast RNA, serving as a negative control for both EGF and $\mathrm{TGF}_{-} \alpha$ solution hybridization assays, was tested for its inability to protect EGF- or TGF- $\alpha$-specific RNA probes from ribonuclease digestion. As shown in the zero lanes of their respective standard curve autoradiographs (Fig. 3, upper panels), EGF- and TGF- $\alpha$-protected bands were absent in the presence of total yeast RNA alone, thereby confirming the complete removal of all unhybridized radiolabeled probe. 


\section{EPIDERMAL GROWTH FACTOR}
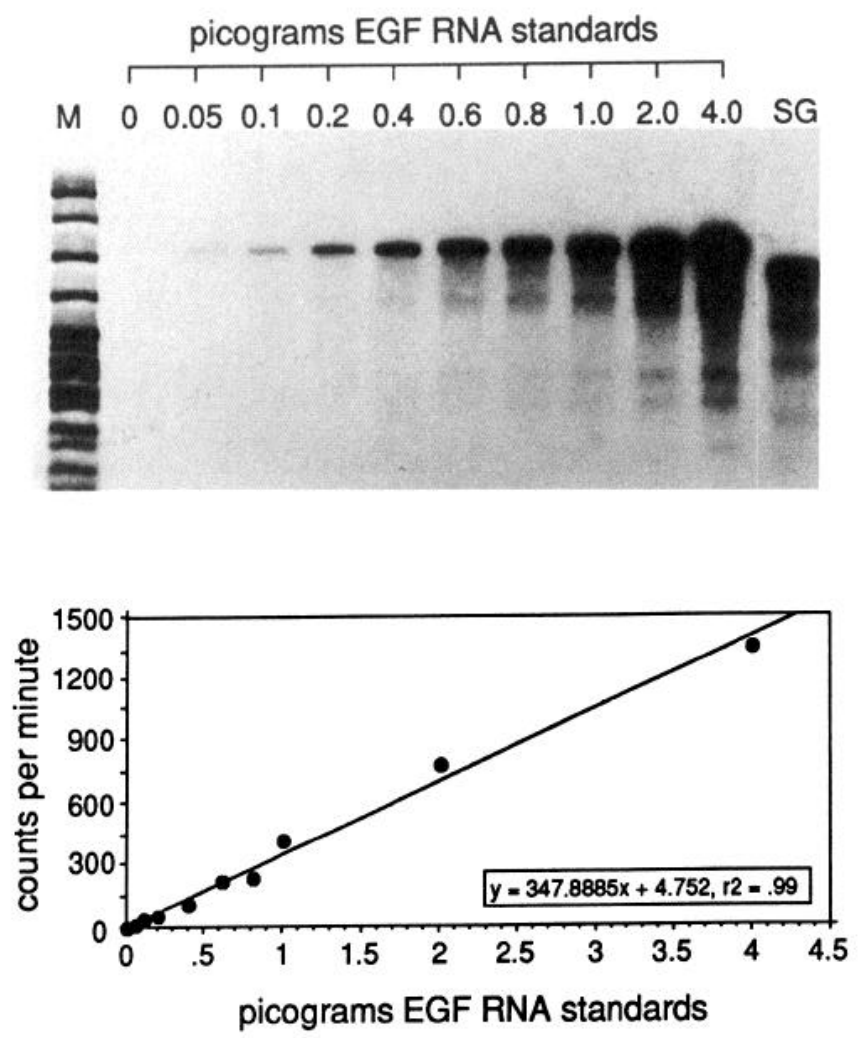

\section{TRANSFORMING GROWTH FACTOR- $\alpha$}
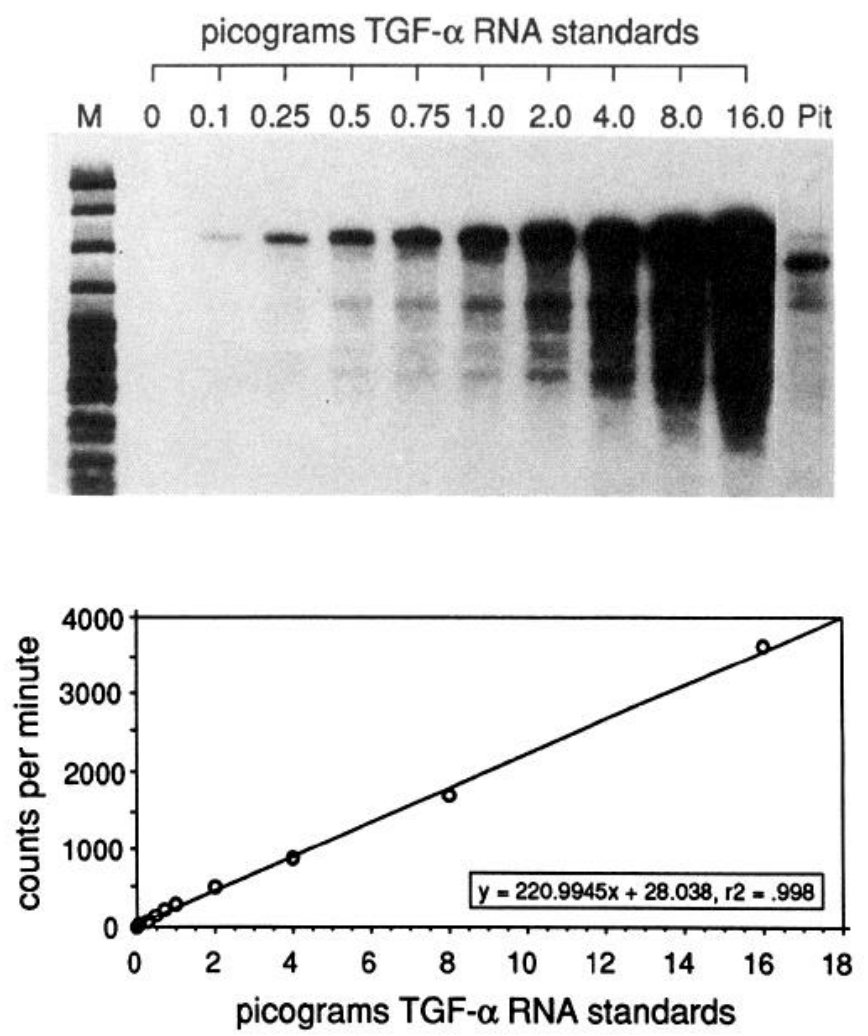

Figure 3. Standard curves of EGF and TGF- $\alpha$ ribonuclease protection assays. Upper panels, Representative autoradiographs of EGF and TGF- $\alpha$ standard curves are shown, demonstrating the linear relationship between increasing quantities of in vitro-transcribed RNA standards and the intensity of their full-length protected bands. Adult male mouse SG RNA and anterior pituitary (Pit) RNA were used as positive control samples in all EGF and TGF- $\alpha$ assays, respectively. The difference in size between tissue RNA bands ( $S G$ and Pit) and RNA standards, shown in reference to ${ }^{35}$ S-labeled MspI-pBR322 DNA markers $(M)$, was a result of short vector sequences transcribed during the in vitro synthesis of RNA probes and standards. These sequences were not complementary to tissue mRNA sequences and consequently were trimmed away during ribonuclease digestion. No protected bands were observed in zero lanes containing total yeast RNA alone. Autoradiographic exposure, $14 \mathrm{hr}$ at $-80^{\circ} \mathrm{C}$ with an intensifying screen. (Note: Protected bands were not visible in the zero lanes of autoradiographs even after exposing gels for as long as $70 \mathrm{hr}$.) Lower panels, Following the exposure of dried gels to x-ray film, full-length protected gel bands were cut out (using the autoradiograph as a guide) and quantitated by liquid scintillation counting. Linear regression analysis of the relationship between known quantities of RNA standards and the cpm present in their protected bands (shown graphically) provided a mathematical equation for transforming tissue RNA cpm values to mass quantities.

\section{Regional distribution of EGF and TGF- $\alpha$ mRNA in the mature murine CNS}

EGF mRNA was detected in all adult male brain regions examined as well as whole pituitary, with autoradiographic confirmation of discrete, full-length protected bands (Fig. 4). In the CNS, EGF mRNA (Fig. 5, upper graph) was most abundant in the olfactory bulbs $(36 \pm 3 \mathrm{fg} / \mu \mathrm{g}$ ) and basal hypothalamus (30 $\pm 3 \mathrm{fg} / \mu \mathrm{g}$ ), while lower levels were detected in cerebellum (24 $\pm 4 \mathrm{fg} / \mu \mathrm{g})$, olfactory tubercle $(21 \pm 1 \mathrm{fg} / \mu \mathrm{g})$, brainstem $(20 \pm$ $3 \mathrm{fg} / \mu \mathrm{g})$, striatum $(17 \pm 3 \mathrm{fg} / \mu \mathrm{g})$, hippocampus $(14 \pm 1 \mathrm{fg} / \mu \mathrm{g})$, thalamus $(12 \pm 2 \mathrm{fg} / \mu \mathrm{g})$, and cerebral cortex $(11 \pm 2 \mathrm{fg} / \mu \mathrm{g})$. Adult pituitary, a region derived in part from the developing CNS but shown to express EGF within its anterior lobe (Kasselberg et al., 1985), contained $234 \pm 10 \mathrm{fg}$ EGF mRNA/ $\mu \mathrm{g}, 6-$ 20 times the levels present in regions of brain (Fig. 5, upper graph). Adult male SG contained $432 \pm 3 \mathrm{pg}$ EGF mRNA $/ \mu \mathrm{g}$, approximately 2000 times the levels in male pituitary and 4 orders of magnitude greater than the levels present in adult brain (Fig. 6).
TGF- $\alpha$ mRNA levels in brain were 15-170 times greater than the regional levels quantitated for EGF (Fig. 5, lower graph). While clearly highest in the striatum $(2.93 \pm 0.22 \mathrm{pg} / \mu \mathrm{g})$, a relative abundance of TGF- $\alpha$ mRNA was also noted for the olfactory tubercle $(1.71 \pm 0.05 \mathrm{pg} / \mu \mathrm{g})$ and olfactory bulb $(1.28$ $\pm 0.09 \mathrm{pg} / \mu \mathrm{g}$ ) (Fig. 5, lower graph). Slightly lower levels were observed in brainstem $(0.84 \pm 0.11 \mathrm{pg} / \mu \mathrm{g})$, hippocampus $(0.82$ $\pm 0.09 \mathrm{pg} / \mu \mathrm{g})$, thalamus $(0.72 \pm 0.10 \mathrm{pg} / \mu \mathrm{g})$, and hypothalamus $(0.67 \pm 0.13 \mathrm{pg} / \mu \mathrm{g})$, while the concentrations in cerebral cortex and cerebellum (each $0.39 \mathrm{pg} / \mu \mathrm{g}$ ) were the lowest among all CNS regions examined. TGF- $\alpha$ mRNA in adult male pituitary $(215 \pm 12 \mathrm{fg} / \mu \mathrm{g})$, less than all levels observed in brain, were nearly equal to the pituitary levels of EGF mRNA (Figs. 5, 6C). No TGF- $\alpha$ mRNA was detected in cytoplasmic RNA isolated from adult male SG.

\section{Sex differences in EGF and TGF- $\alpha$ mRNA levels}

Consistent with the order-of-magnitude differences reported between sexes for both EGF protein and preproEGF mRNA (Byyny et al., 1972; Rall et al., 1985), EGF mRNA levels in the adult 


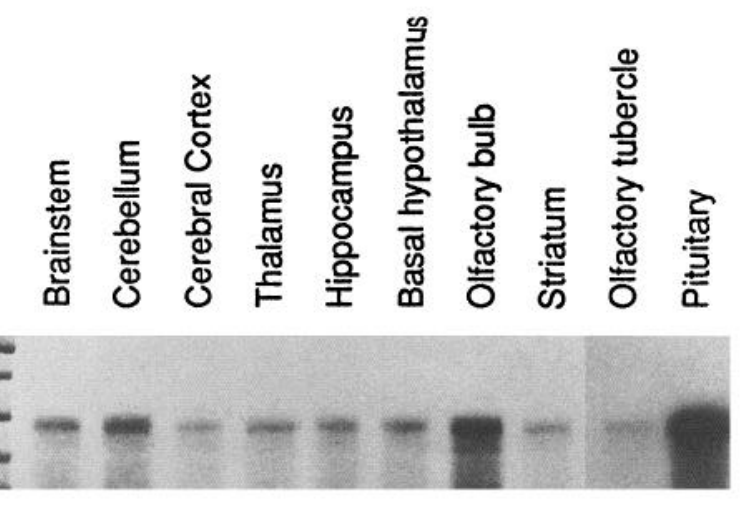

Figure 4. Ribonuclease protection analysis of EGF mRNA in defined regions of the adult male mouse CNS and pituitary. Total cytoplasmic RNA isolated from brain regions and whole pituitary was assayed for the presence of mRNA complementary to the 344 nucleotide EGFspecific riboprobe sequence. Full-length protected RNA bands, shown in reference to MspI-digested pBR322 DNA markers, were evident in all sample lanes. Quantities of total cytoplasmic RNA assayed were as follows: $100 \mu \mathrm{g}$ for brainstem, cerebellum, cerebral cortex, thalamus, hippocampus, olfactory bulb, and striatum; $75 \mu \mathrm{g}$ for whole pituitary; $50 \mu \mathrm{g}$ for basal hypothalamus and olfactory tubercle. All samples were standardized to a final quantity of $100 \mu \mathrm{g}$ RNA by the addition of total yeast RNA. The autoradiographic image represents a $24 \mathrm{hr}$ exposure at $-80^{\circ} \mathrm{C}$ with an intensifying screen.

male SG $(432 \pm 3 \mathrm{pg} / \mu \mathrm{g})$ were significantly higher than the levels detected in mature females $(15 \pm 1 \mathrm{pg} / \mu \mathrm{g}$ ) (Fig. $6 A$ ). In adult pituitary (Fig. $6 C$ ), the level of EGF mRNA in males $(0.23 \pm$ $0.01 \mathrm{pg} / \mu \mathrm{g})$ was also significantly higher than in females $(0.17$ $\pm 0.01 \mathrm{pg} / \mu \mathrm{g}$ ), as were TGF- $\alpha$ mRNA levels between adult males $(0.22 \pm 0.01 \mathrm{pg} / \mu \mathrm{g})$ and females $(0.12 \pm 0.02 \mathrm{pg} / \mu \mathrm{g})$. Male-female pituitary mRNA levels compared between growth factors, however, revealed a greater sex difference for TGF- $\alpha$ mRNA, with female values $54 \%$ below the levels detected in males; EGF mRNA in the adult female pituitary was only $26 \%$ below its respective male value. Despite sexual differences in glandular levels of growth factor mRNA transcripts, no significant differences between sexes were observed in regions of adult brain for either EGF (Fig. 6B) or TGF- $\alpha$ mRNA (data not shown).

\section{Developmental expression of EGF and TGF- $\alpha \mathrm{mRNA}$}

EGF mRNA in the developing brain was detectable as early as E14 (earliest time point studied) (Fig. 7). While levels appeared relatively stable into the early postnatal period (averaging 47 $\mathrm{fg} / \mu \mathrm{g}$ total RNA between E14 and P1), the expression of EGF mRNA by P10 dropped by more than half the levels observed $1 \mathrm{~d}$ after birth (Fig. $8 A$, upper graph). By contrast, TGF- $\alpha$ mRNA levels rose between E14 and P1 (reaching $\sim 3 \mathrm{pg} / \mu \mathrm{g}$ total RNA) and subsequently, fell by $\sim 55 \%$ by P10 (Fig. $8 A$, lower graph).

Total brain RNA content between E14 and P10, an index of general brain growth, was 57 (E14), 91 (E15), 114 (E16), 143 (E17), 166 (P1), and 585 (P10) $\mu \mathrm{g} /$ brain (averaged from two litters of each age). When levels of EGF and TGF- $\alpha$ mRNA in the developing CNS were expressed per individual brain, the observed patterns of mRNA expression for both growth factors appeared similar, with total EGF mRNA (Fig. $8 B$, upper graph) and total TGF- $\alpha$ mRNA (Fig. $8 B$, lower graph) increasing throughout perinatal development, though an order-of-magnitude difference between EGF (3-11 pg mRNA/brain) and TGF- $\alpha$

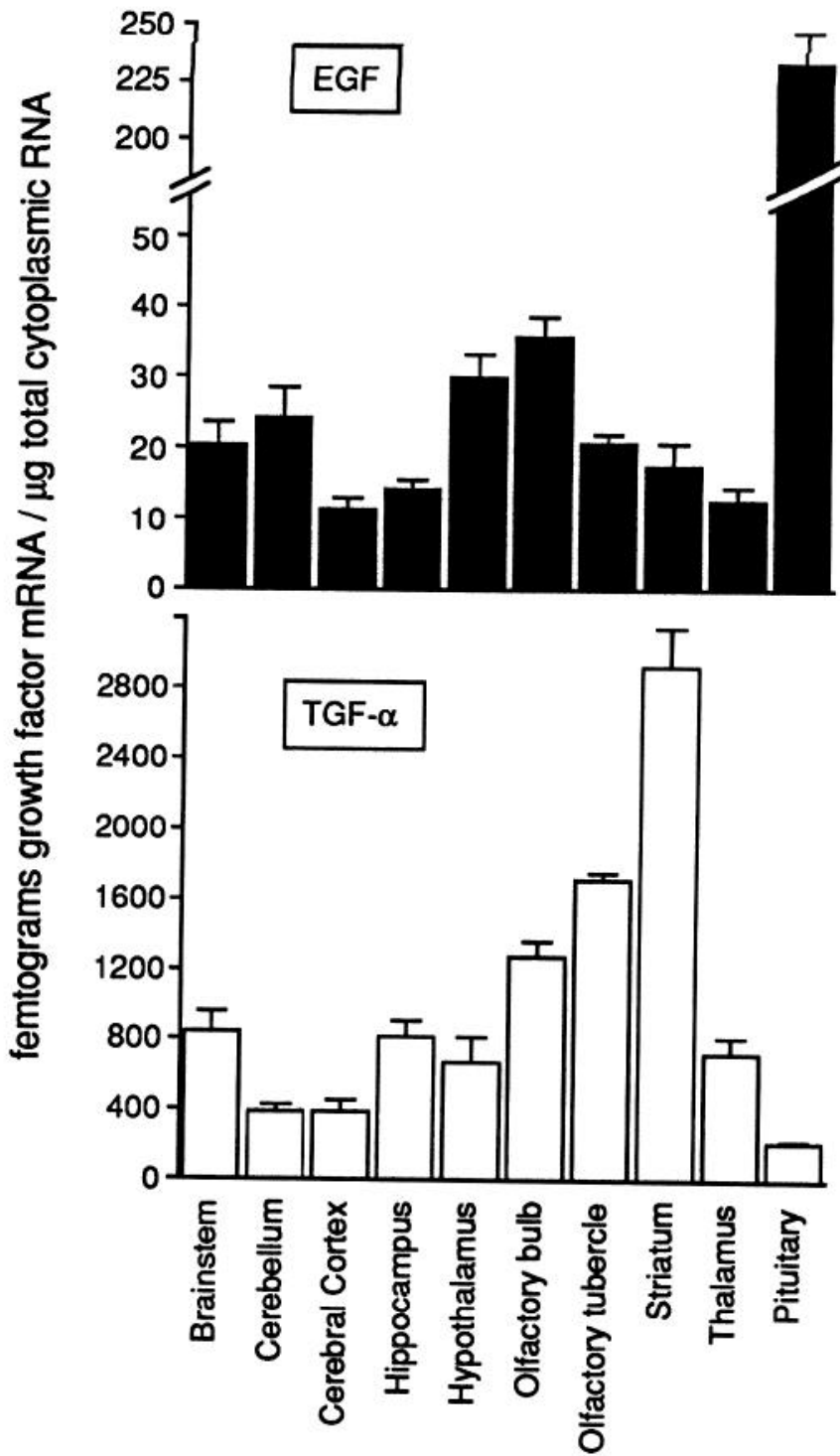

Figure 5. EGF and TGF- $\alpha$ mRNA levels in adult male mouse CNS and pituitary. Total cytoplasmic RNA isolated from anatomically defined brain regions and whole pituitary were assayed for the quantitation of EGF and TGF $-\alpha$ mRNA (see Materials and Methods for quantitative procedures). The number of independent assay determinations $(n)$ performed for each region were as follows: $n=6$ for brainstem, cerebellum, cerebral cortex, hippocampus, olfactory bulb, and thalamus; $n=3$ for basal hypothalamus, olfactory tubercle, and whole pituitary; $n=2$ for striatum. Values represent the mean \pm SEM for each region.

(39-691 pg/brain) mRNA values was observed. Whereas total brain RNA content increased 3.5-fold between P1 and P10 (from an average of $166 \mu \mathrm{g}$ total brain cytoplasmic RNA to $585 \mu \mathrm{g}$ ), EGF and TGF- $\alpha$ total mRNA in whole brain (Fig. $8 B$ ) increased by only $25 \%$ and $54 \%$, respectively. This decrease in relative abundance of EGF and TGF- $\alpha$ mRNA compared to total brain RNA content, then, was reflected by the lower EGF and TGF- $\alpha$ mRNA concentrations observed $10 \mathrm{~d}$ after birth (Fig. $8 A$ ).

\section{Discussion}

This study provides the first specific, quantitative evidence for the expression of EGF mRNA in brain and expands upon reported findings concerning TGF- $\alpha$ gene expression in the CNS. 
A

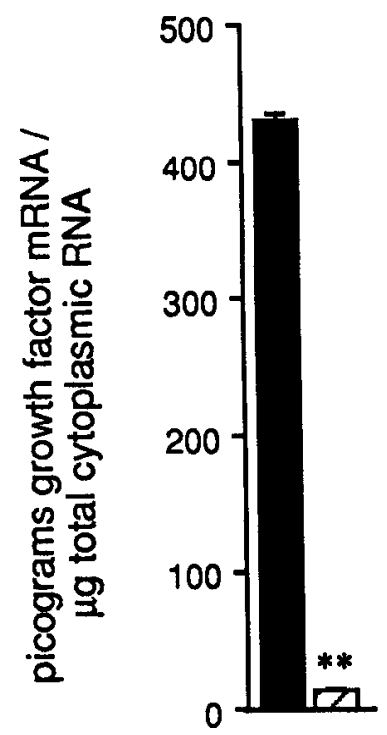

Submaxillary
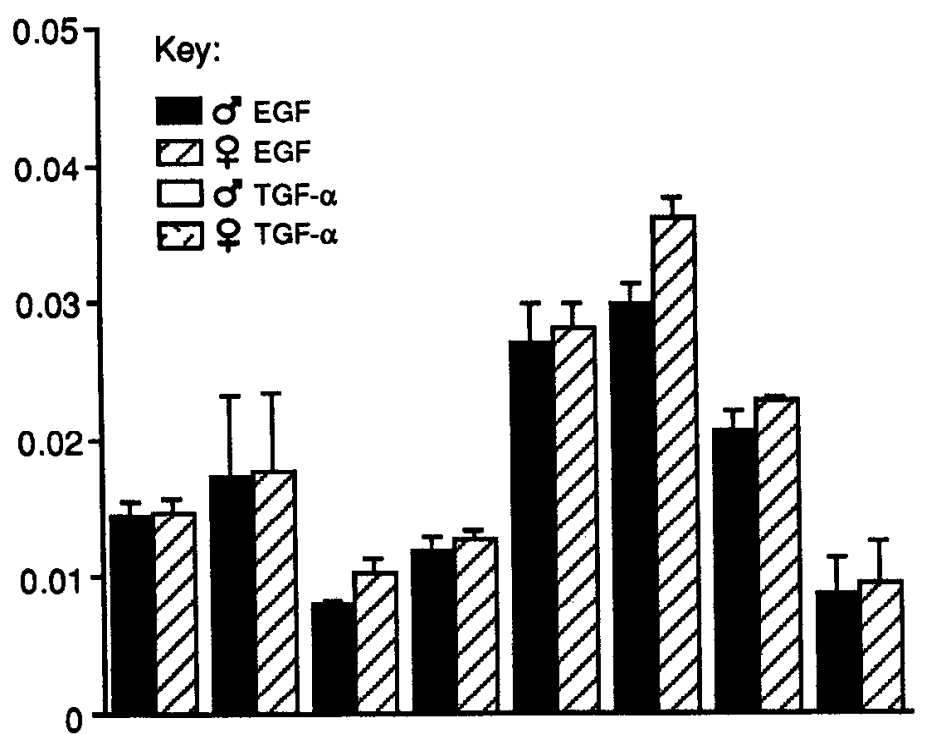

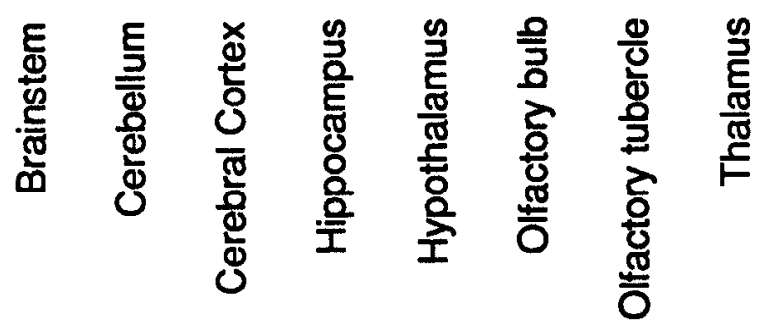

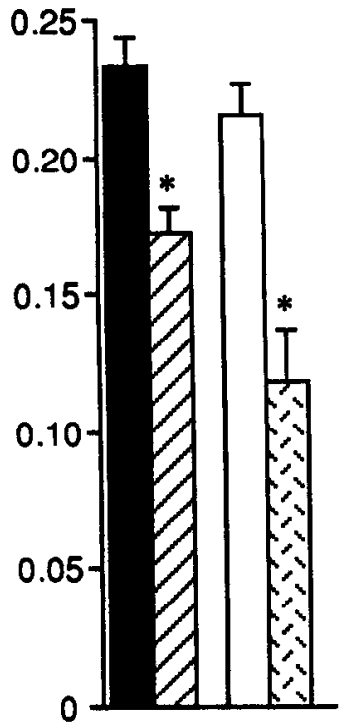

Pituitary

Figure 6. Comparison of EGF and TGF- $\alpha$ mRNA levels between sexes. Total cytoplasmic RNA isolated from male and female adult mouse SG, brain regions, and whole pituitary were assayed for the quantitation of EGF and TGF- $\alpha$ mRNA. Tissue collected from female mice were taken at random stages of the estrous cycle. To minimize the variability introduced during the handling of samples, RNA extractions and assay analyses for tissues matched by sex were performed simultaneously. The analysis of striatum was excluded due to the prohibitive number of animals required for adequate quantities of total RNA. Values represent the mean \pm SEM of three independent determinations. $A$, EGF mRNA levels in adult SG revealed significantly higher levels in males compared to females $\left({ }^{* *}, p<0.0001\right.$, Student's $t$ test). $B$, No significant difference between sexes was observed for the expression of EGF mRNA in adult brain regions $(p=0.2$, ANOVA). $C$, EGF and TGF- $\alpha$ mRNA levels present in adult male pituitary were significantly greater than their respective female values $\left({ }^{*}, p=0.01\right.$, Student's $t$ test).

Our comparison of the regional distribution, differences between sexes, and developmental profile of EGF and TGF- $\alpha$ mRNAs in mouse brain suggests that both EGF and TGF- $\alpha$ may play a role in the growth and support of the mammalian CNS.

\section{Regional codistribution of EGF and TGF- $\alpha \mathrm{mRNAs}$ in adult brain}

mRNAs for both EGF and TGF- $\alpha$ were detected in all regions of the mature CNS studied, including brainstem, cerebellum, cerebral cortex, hippocampus, basal hypothalamus, olfactory bulb, olfactory tubercle, striatum, and thalamus. Despitc this overlap in distribution, TGF- $\alpha$ mRNA levels, quantitated in the $\mathrm{pg} / \mu \mathrm{g}$ range, were $15-170$ times greater than the $\mathrm{fg} / \mu \mathrm{g}$ levels observed for EGF mRNA. Highest concentrations of EGF gene transcripts were in the olfactory bulb and basal hypothalamus, while TGF- $\alpha$ mRNA levels were highest in the striatum and olfactory tubercle. The cerebellum, containing a relative abundance of EGF mRNA, was among the regions expressing the lowest levels of TGF- $\alpha$ mRNA.

The presence of both EGF and TGF- $\alpha$ gene transcripts in brain, together with previous immunological data (Fallon et al.,
1984, 1990; Lakshmanan et al., 1986; Fallon, 1987; Kudlow et al., 1989; Schaudies et al., 1989; Brown et al., 1990), provides evidence to support local synthesis of both EGF-R ligands in the mammalian CNS. Recently, Ojeda et al. (1990) suggested that the low EGF mRNA levels detected in brain reflected a limited ability on the part of the CNS to synthesize EGF. Our findings reflect levels of EGF and TGF- $\alpha$ mRNA within whole anatomic regions containing a diversity of cell types and subpopulations, and therefore it is possible that EGF mRNA synthesis within any given brain region is occurring in only a small number of cells. Interestingly, mRNA levels for NGF in the CNS (Shelton and Reichardt, 1986) are comparable to those of EGF. From this standpoint, TGF- $\alpha$ gene expression itself is out of the range of what is traditionally representative of a neurotrophic agent. The striking differences in mRNA levels, then, potentially reflect the functional specificities of EGF and TGF- $\alpha$ in the CNS.

While our identification of both EGF and TGF- $\alpha$ mRNAs in brain is consistent with local synthesis, the biological form(s) of their respective peptides in brain remains unknown. Previous examinations of the cDNAs encoding EGF and TGF- $\alpha$ indicate 


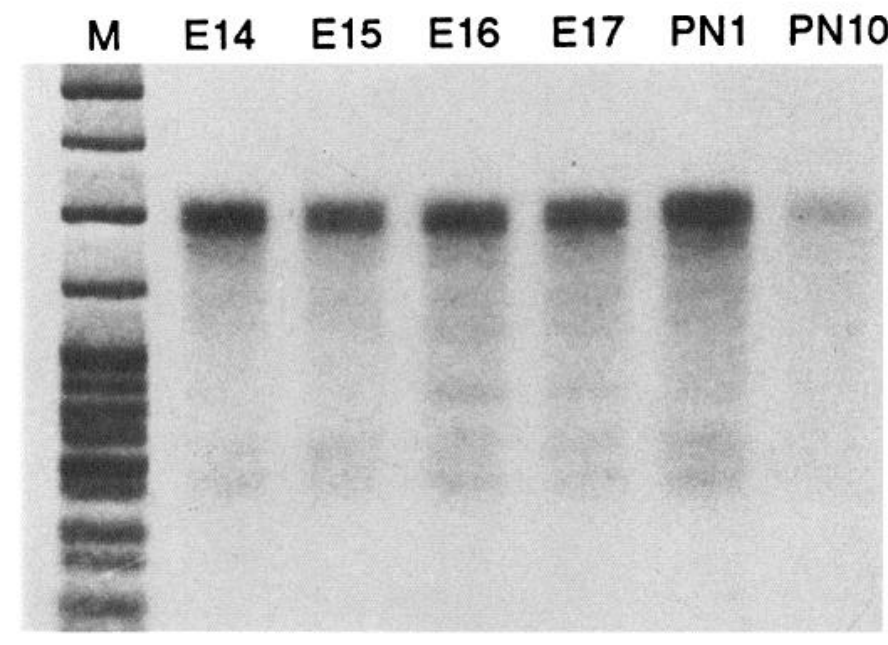

Figure 7. Ribonuclease protection analysis of EGF mRNA expression in prenatal and early postnatal mouse brain. $M,{ }^{35}$ S-labeled MspI/pBR322 DNA marker; $E 14-E 17$, analysis of embryonic brain cytoplasmic RNA derived from E14, E15, E16 and E17 fetuses; $P 1$ and P10, analysis of postnatal brain cytoplasmic RNA derived from P1 and P10 pups. All samples contained $75 \mu \mathrm{g}$ total cytoplasmic RNA derived from brains of individual litters. The autoradiographic image represents a $24 \mathrm{hr}$ exposure at $-80^{\circ} \mathrm{C}$ with an intensifying screen.

that the mature forms of these peptides are derived from larger precursor molecules with structural features common to transmembrane proteins (Gray et al., 1983; Scott et al., 1983; Derynck et al., 1984; Lee et al., 1985a; Bell et al., 1986). Since proteolytic processing of the EGF and TGF- $\alpha$ precursors may not be required for biological activity, it is possible that the membrane-anchored, unprocessed forms of these proteins serve as active forms of EGF and TGF- $\alpha$ in brain (Brachmann et al., 1989; Mroczkowski et al., 1989; Wong et al., 1989; Breyer and Cohen, 1990). In kidney, in which the unprocessed EGF precursor molecule is reported to accumulate (Rall et al., 1985), it has been suggested that the proEGF precursor molecule might serve as a cell surface receptor in addition to generating mature EGF (Pfeffer and Ullrich, 1985). If unprocessed EGF were the predominant form present in the CNS, this could explain why some investigators have not detected EGF-immunoreactive material in brain (Probstmeier and Schachner, 1986; Beerstecher et al., 1988) while others have (Fallon et al., 1984; Lakshmanan et al., 1986). More specifically, with EGF antibodies routinely raised against the 53 amino acid processed form of the mature EGF peptide, differences in antigenic determinants between processed and unprocessed EGF could result in a lack of EGF immunostaining for CNS tissue. Unlike the TGF- $\alpha$ precursor protein, however, which codes only for the mature TGF- $\alpha$ peptide, the EGF precursor also contains seven to nine EGF-like peptide sequences (Fig. 2), each sharing varying degrees of homology with EGF itself. Although conflicting opinions have been offered regarding the potential for proteolytic release of these peptides from the EGF precursor (Gray et al., 1983; Scott et al., 1983; Doolittle et al., 1984), the presence of multiple EGF-like immunoreactive species in rat brain (Schaudies et al., 1989) potentially reflects differential processing of the full-length precursor in the CNS. Thus, the presence of EGF and TGF- $\alpha$ gene transcripts in brain provides a biochemical basis for multiple EGF-R ligands to be endogenously expressed in the mammalian CNS.
Perhaps the most intriguing finding of the present study is the regional codistribution of EGF and TGF- $\alpha$ mRNAs. As both EGF and TGF- $\alpha$ are believed to utilize a common EGF-R in vivo (Carpenter et al., 1983; Marquardt et al., 1983, 1984; Massagué, 1983), the mechanism by which either peptide might achieve different biological effects in any particular region of the nervous system remains unclear. Currently, there is no experimental evidence to support the existence of EGF-R subtypes in vivo. However, differences in the biological potencies or activities of EGF and TGF- $\alpha$ have been observed (Ibbotson et al., 1986; Schreiber et al., 1986; Barrandon and Green, 1987; Gan et al., 1987). Winkler et al. (1989) recently proposed that differences in EGF- and TGF- $\alpha$-mediated effects might result from (1) differences in growth factor binding sites in the EGF-R or (2) differences in receptor conformations induced upon binding. Decker (1990) has suggested that differential processing of the EGF-R following EGF or TGF- $\alpha$ binding could account for differences in growth factor-specific potencies. It is possible, however, that in addition to receptor mechanisms mediating potential differences in EGF and TGF- $\alpha$ activities in brain, microregional differences in the distribution of EGF and TGF- $\alpha$ in the CNS may restrict their local availability for binding to cell-specific EGF-R.

Perhaps one of the most favored hypotheses concerning potential differences in activities of EGF and TGF- $\alpha$ in brain is that one peptide originates in glia while the other is generated by neurons. At present, the glial and/or neuronal sites of EGF and TGF- $\alpha$ mRNA synthesis in the CNS remain unknown. While data obtained from immunological studies tend to suggest a neuronal source for EGF (Fallon et al., 1984; Lakshmanan et al., 1986), TGF- $\alpha$-immunoreactive material has been observed in bóth neurons (Fallon, 1987; Kudlow et al., 1989) and glia (Fallon et al., 1990). A recent study using in situ hybridization histochemistry to localize TGF- $\alpha$ mRNA in mouse brain has revealed a predominantly neuronal distribution of labeled cells (Wilcox and Derynck, 1988). In view of the low regional concentrations of EGF mRNA present in mouse brain, an extremely sensitive in situ hybridization protocol will most likely be required to identify the glial or neuronal source of EGF gene expression in the mammalian CNS.

\section{Sex differences in growth factor gene expression are tissue specific}

Previous studies have reported sex differences in the levels of EGF or EGF mRNA in a variety of adult mouse tissues and fluids. For the SG, EGF peptide and mRNA concentrations have been observed as significantly higher in males than in females (Byyny et al., 1972; Rall et al., 1985). Similarly, quantitation of EGF in blood serum and liver has revealed higher levels in males (Perheentupa et al., 1985a; Laborde et al., 1988). In contrast, both kidney and urine concentrations of EGF have been shown to be higher in females (Perheentupa et al., 1985b). In view of observed male-female differences in axonal sprouting following induced lesions in the CNS (Loy and Milner, 1980) and the ability of EGF to promote neurite outgrowth in culture (Morrison et al., 1987, 1988; Casper et al., 1991), we were interested in whether the levels of EGF gene expression in brain might also show differences between sexes and, if so, whether such differences might be paralleled by the expression of TGF- $\alpha$ mRNA.

From our studies, no significant sex differences were apparent in any region of the CNS for either EGF or TGF- $\alpha$ mRNAs. 


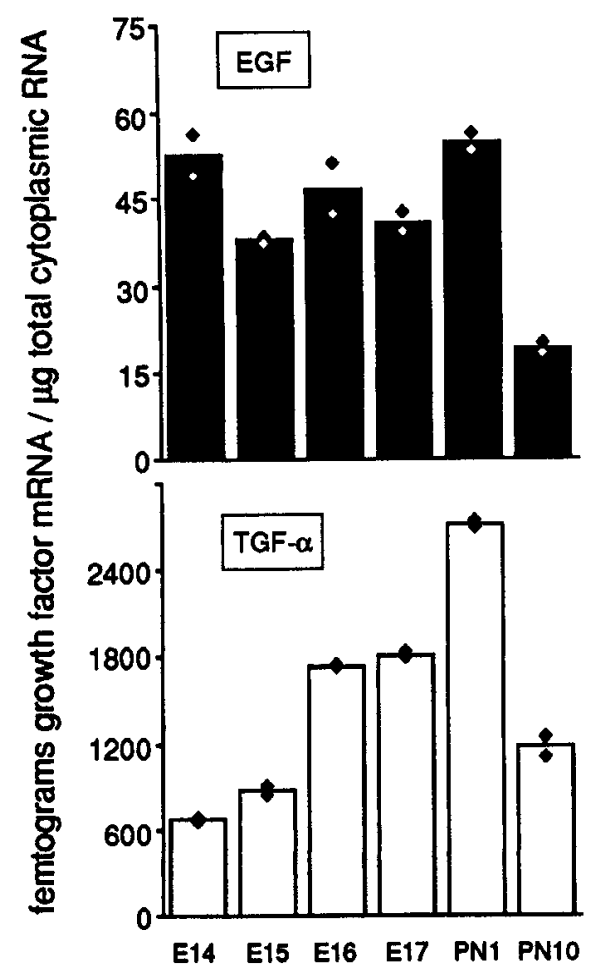

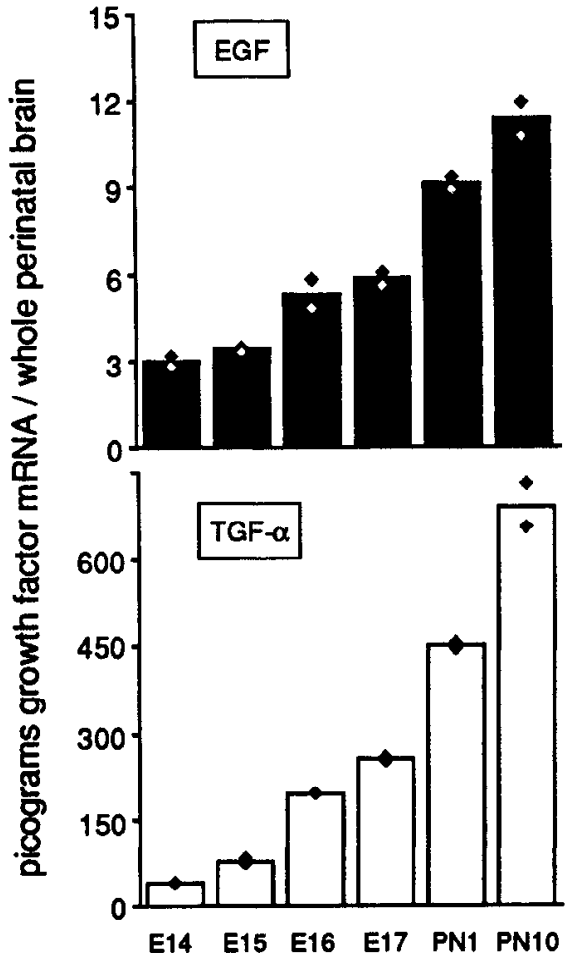

Figure 8. Expression of $\mathrm{EGF}$ and TGF- $\alpha$ mRNA in the developing CNS. Embryonic whole brain from E14, E15, $\mathrm{E} 16$, and $\mathrm{E} 17$ mouse fetuses and postnatal whole brain from $\mathrm{P} 1$ and $\mathrm{P} 10$ pups were processed for the isolation of total cytoplasmic RNA and assayed by ribonuclease protection analysis. Levels of EGF and TGF- $\alpha$ mRNA are expressed per microgram total RNA $(A)$ or per whole perinatal brain $(B)$. Bars represent the average of two independent assay determinations (each indicated with a diamond).
Even for the basal hypothalamus, in which androgen and estrogen receptors are relatively abundant, no significant malefemale difference in growth factor gene expression was observed. However, since we did not use estrous-staged mice for our study, we do not rule out the possibility that femalc levels of EGF mRNA vary during the course of the estrous cycle.

In the adult pituitary, also known to be a rich source of gonadal steroid hormone receptors, significantly higher levels of EGF and TGF- $\alpha$ mRNAs were observed in males. Recently, Pascall and Brown (1988) located sequences in the $5^{\prime}$ flanking region of the mouse EGF gene, homologous to sequences present in other genes known to be regulated by testosterone. In view of these findings, the sex difference in pituitary EGF mRNA levels could reflect androgen:receptor:DNA binding interactions that directly promote EGF transcriptional changes in this tissue. Alternatively, differences in levels of EGF mRNA between male and female pituitary might reflect sex differences in the numbers of each of the hormone-secreting cell types within the anterior lobe. Thus, with the expression of EGF apparently limited to the gonadotroph and thyrotroph cell populations (Kasselberg et al., 1985), the greater abundance of lactotrophs in female pituitary (Velkeniers et al., 1988) would lower the observed concentration of EGF mRNA in females below that of males. A similar argument, however, cannot easily be made for the malefemale difference in TGF- $\alpha$ mRNA levels, as this peptide has previously been localized to the lactotroph cell population (Kobrin et al., 1987). Therefore, unless TGF- $\alpha$ was sequestered within lactotrophs following its synthesis in some other cell type, the levels of TGF- $\alpha$ mRNA in female pituitary would be expected to be higher or at least equal to the levels detected in males. Further studies then are necessary to determine whether the sex difference in TGF- $\alpha$ mRNA expression may be due to differences in gonadal steroid hormone expression.

\section{Coexpression of EGF and TGF- $\alpha m R N A$ s in fetal and early postnatal brain}

This study provides the only evidence to date for the expression of EGF mRNA in fetal brain. The lack of information concerning EGF gene expression during embryogenesis has led to speculations that TGF- $\alpha$ is the fetal analog of EGF (Proper and Moses, 1981; Lee et al., 1985b; Twardzik, 1985; Popliker et al., 1987). Our findings now suggest that both EGF and TGF- $\alpha$ may participate in normal CNS developmental processes. Consistent with our data, EGF-R are present in mouse brain as early as $\mathrm{E} 15$ and in a manner similar to the rise in TGF- $\alpha$ mRNA, EGF-R increase in number throughout late embryonic brain development (Adamson and Meek, 1984).

At present, the role of EGF or TGF- $\alpha$ in brain development remains unknown. Studies performed in culture have shown that specific populations of neurons and glia derived from fetal brain are responsive to the effects of EGF (Simpson et al., 1982; Honegger and Guentert-Lauber, 1983; Morrison et al., 1987, 1988; Knusel et al., 1990; Casper et al., 1991). In a preliminary report by Reynolds et al. (1990), EGF and TGF- $\alpha$ have been shown to stimulate the proliferation of striatal multipotential progenitor cells in vitro. Interestingly, the cellular morphologies induced by TGF- $\alpha$ were somewhat different than those produced by EGF (Reynolds et al., 1990). In view of these findings and the strikingly different levels of EGF and TGF- $\alpha$ mRNAs present in fetal brain, EGF and TGF- $\alpha$ are likely to have unique roles in the development of the mammalian CNS. 


\section{Functional implications}

The potential for EGF and TGF- $\alpha$ to utilize a common receptor in vivo underscores the difficulty in assigning physiological roles specific to each peptide based on anatomic characterizations alone. While it is still not clear which cells in the brain actually synthesize EGF or TGF- $\alpha$, the potential for both ligands to compete locally for EGF-R binding suggests that a variety of mechanisms may be involved in regulating growth factor-specific activities in the CNS. In this light, studies addressing specific changes in growth factor gene expression during the course of normal brain development or in response to brain injury are likely to contribute to our understanding of why two EGF-R ligands are physiologically required in this tissue. Further studies in our laboratory using mutant mice exhibiting selective neurodegenerative losses of cells known to express EGF receptors have revealed unique patterns of gene expression for EGF and TGF- $\alpha$ during specific neuronal or glial events (L. M. Lazar and $M$. Blum, unpublished observations). In view of such differences, it is unlikely that these structurally related peptides simply reflect a biochemical redundancy in the normal functioning of the mammalian CNS. More likely, EGF and TGF- $\alpha$ in brain serve within a multifunctional growth factor system whose members interact via a common membrane receptor.

\section{References}

Adamson ED, Meek J (1984) The ontogeny of epidermal growth factor receptors during mouse development. Dev Biol 103:62-70.

Barrandon Y, Green H (1987) Cell migration is essential for the sustained growth of keratinocyte colonies: the roles of transforming growth factor- $\alpha$ and epidermal growth factor. Cell 50:1131-1137.

Beerstecher HJ, Huiskens-Van Der Meij C, Warnaar SO (1988) An immunohistochemical study performed with monoclonal and polyclonal antibodies to mouse epidermal growth factor. J Histochem Cytochem 36:1153-1160.

Bell GI, Fong NM, Stempie NM, Wormsted MA, Caput DF, Ku L, Urdea MS, Rall LB, Sanchez-Pescador R (1986) Human epidermal growth factor precursor: cDNA sequence, expression in vitro and gene organization. Nucleic Acids Res 14:8427-8446.

Blum M (1989) Regulation of neuroendocrine peptide gene expression. In: Methods in enzymology, Vol 168, Hormone action, Pt K, Neuroendocrine peptides (Conn PM, ed), pp 618-633. San Diego: Academic.

Borgundvaag B, Kudlow JE, Mueller S, George SR (1990) Transforming growth factor-alpha (TGF- $\alpha$ ) messenger RNA in anterior pituitary: stimulation by estrogen and inhibition by bromocriptine. Endocr Soc Abstr 72:181.

Brachmann R, Lindquist PB, Nagashima M, Kohr W, Lipari T, Napier M, Derynck R (1989) Transmembrane TGF- $\alpha$ precursors activate EGF/TGF- $\alpha$ receptors. Cell 56:691-700.

Breyer JA, Cohen S (1990) The epidermal growth factor precursor isolated from murine kidney membranes. Chemical characterization and biological properties. J Biol Chem 265:16564-16570.

Brown PI, Lam R, Lakshmanan J, Fisher DA (1990) Transforming growth factor alpha in developing rats. Am J Physiol 259:E256-E260.

Byyny RL, Orth DN, Cohen S (1972) Radioimmunoassay of epidermal growth factor. Endocrinology 90:1261-1266.

Carpenter G, Cohen S (1979) Epidermal growth factor. Annu Rev Biochem 48:193-216.

Carpenter G, Wahl MI (1990) The epidermal growth factor family. In: Peptide growth factors and their receptors I (Sporn MB, Roberts $A B$, eds), pp 69-171. New York: Springer.

Carpenter G, Stoscheck CM, Preston YA, DeLarco JE (1983) Antibodies to the epidermal growth factor receptor block the biological activities of sarcoma growth factor. Proc Natl Acad Sci USA 80:56275630.

Casper D, Mytilineou C, Blum M (1991) EGF enhances the survival of dopamine neurons in rat embryonic mesencephalon primary cell culture. J Neurosci Res 30:372-381.

Chabot JG, Araujo DM, Quirion R (1988) Epidermal growth factor
(EGF) binding sites in adult rat brain and pituitary gland. An in vitro autoradiographic study. Soc Neurosci Abstr 14:1073.

Cohen S (1962) Isolation of a mouse submaxillary gland protein accelerating incisor eruption and eyelid opening in the newborn animal. J Biol Chem 237:1555-1562.

Decker SJ (1990) Epidermal growth factor and transforming growth factor-alpha induce differential processing of the epidermal growth factor receptor. Biochem Biophys Res Commun 166:615-621.

Derynck R, Roberts AB, Winkler ME, Chen EY, Goeddel DV (1984) Human transforming growth factor- $\alpha$ : precursor structure and expression in E. coli. Cell 38:287-297.

Doolittle RF, Feng DF, Johnson MS (1984) Computer-based charactcrization of cpidermal growth factor precursor. Nature 307:558560.

Fallon JH (1987) Growth factors in the basal ganglia. In: The basal ganglia II: structure and function-current concepts (Carpenter MB, Jayaraman A, eds), pp 247-260. New York: Plenum.

Fallon JH, Seroogy KB, Loughlin SE, Morrison RS, Bradshaw RA, Knauer DJ, Cunningham DD (1984) Epidermal growth factor immunoreactive material in the central nervous system: location and development. Science 224:1107-1109.

Fallon JH, Annis CM, Gentry LE, Twardzik DR, Loughlin SE (1990) Localization of cells containing transforming growth factor- $\alpha$ precursor immunoreactivity in the basal ganglia of the adult rat brain. Growth Factors 2:241-250.

Gan BS, Hollenberg MD, MacCannell KL, Lederis K, Winkler ME, Derynck R (1987) Distinct vascular actions of epidermal growth factor-urogastrone and transforming growth factor- $\alpha$. J Pharmacol Exp Ther 242:331-337.

Gómez-Pinilla F, Knauer DJ, Nieto-Sampedro M (1988) Epidermal growth factor receptor immunoreactivity in rat brain. Development and cellular localization. Brain Res 438:385-390.

Gray A, Dull TJ, Ullrich A (1983) Nucleotide sequence of epidermal growth factor cDNA predicts a 128,000-molecular weight protein precursor. Nature 303:722-725.

Hiramatsu M, Kashimata M, Sato A, Murayama M, Minami N (1988) Influence of age on epidermal growth factor receptor level in the rat brain. Experientia 44:23-25.

Honegger P, Guentert-Lauber B (1983) Epidermal growth factor(EGF) stimulation of cultured brain cells. I. Enhancement of the developmental increase in glial enzymatic activity. Dev Brain Res 11:245251.

Ibbotson KJ, Harrod J, Gowen M, D'Souza S, Smith DD, Winkler ME, Derynck R, Mundy GR (1986) Human recombinant transforming growth factor $\alpha$ stimulates bone resorption and inhibits formation in vitro. Proc Natl Acad Sci USA 83:2228-2232.

Jakubowski M, Roberts JL (1992) Multiplex solution hybridizationRNase protection assay for quantitation of different RNA transcripts from snap-frozen neuroendocrine tissues of individual animals. J Neuroendocrinol 4:in press.

Jørgensen PE, Poulsen SS, Nexø E (1988) Distribution of i.v. administered epidermal growth factor in the rat. Regul Pept 23:161-169.

Kasselberg AG, Orth DN, Gray ME, Stahlman MT (1985) Immunocytochemical localization of human epidermal growth factor/urogastrone in scveral human tissucs. J Histochem Cytochem 33:315322.

Knusel B, Michel PP, Schwaber JS, Hefti F (1990) Selective and nonselective stimulation of central cholinergic and dopaminergic development in vitro by nerve growth factor, basic fibroblast growth factor, epidermal growth factor, insulin and the insulin-like growth factors I and II. J Neurosci 10:558-570.

Kobrin MS, Samsoondar J, Kudlow JE (1986) $\alpha$-Transforming growth factor secreted by untransformed bovine anterior pituitary cells in culture. II. Identification using a sequence-specific monoclonal antibody. J Biol Chem 261:14414-14419.

Kobrin MS, Asa SL, Samsoondar J, Kudlow JE (1987) $\alpha$-Transforming growth factor in the bovine anterior pituitary gland: secretion by dispersed cells and immunohistochemical localization. Endocrinology 121:1412-1416.

Kudlow JE, Leung AWC, Kobrin MS, Paterson AJ, Asa SL (1989) Transforming growth factor- $\alpha$ in the mammalian brain. Immunohistochemical detection in neurons and characterization of its mRNA. J Biol Chem 264:3880-3883.

Laborde NP, Grodin M, Buenaflor G, Brown P, Fisher DA (1988) Ontogenesis of epidermal growth factor in liver of BALB mice. Am J Physiol 255:E28-E32. 
Lakshmanan J, Weichsel ME, Fisher DA (1986) Epidermal growth factor in synaptosomal fractions of mouse cerebral cortex. J Neurochem 46:1081-1085.

Lee DC, Rose TM, Webb NR, Todaro GJ (1985a) Cloning and sequence analysis of a cDNA for rat transforming growth factor- $\alpha$. Nature 313:489-491.

Lee DC, Rochford R, Todaro GJ, Villarreal LP (1985b) Developmental expression of rat transforming growth factor- $\alpha$ mRNA. Mol Cell Biol 5:3644-3646.

Leutz A, Schachner M (1981) Epidermal growth factor stimulates DNA-synthesis of astrocytes in primary cerebellar cultures. Cell Tissue Res 220:393-404.

Loy R, Milner TA (1980) Sexual dimorphism in extent of axonal sprouting in rat hippocampus. Science 208:1282-1284.

Marquardt H, Hunkapiller MW, Hood LE, Twardzik DR, De Larco JE (1983) Transforming growth factors produced by retrovirus-transformed rodent fibroblasts and human melanoma cells: amino acid sequence homology with epidermal growth factor. Proc Natl Acad Sci USA 80:4684-4688.

Marquardt H, Hunkapiller MW, Hood LE, Todaro GJ (1984) Rat transforming growth factor type 1: structure and relation to epidermal growth factor. Science 223:1079-1082.

Massagué J (1983) Epidermal growth factor-like transforming growth factor. II. Interaction with epidermal growth factor receptors in human placenta membranes and A431 cells. J Biol Chem 258:1361413620 .

Morrison RS, Kornblum HI, Leslie FM, Bradshaw RA (1987) Trophic stimulation of cultured neurons from neonatal rat brain by epidermal growth factor. Science 238:72-75.

Morrison RS, Keating RF, Moskal JR (1988) Basic fibroblast growth factor and epidermal growth factor exert differential trophic effects on CNS neurons. J Neurosci Res 21:71-79.

Mroczkowski B, Reich M, Chen K, Bell Gl, Cohen S (1989) Recombinant human epidermal growth factor precursor is a glycosylated membrane protein with biological activity. Mol Cell Biol 9:27712778 .

Nave KA, Probstmeier R, Schachner M (1985) Epidermal growth factor does not cross the blood-brain barrier. Cell Tissue Res 241: 453-457.

Ojeda SR, Urbanski HF, Costa ME, Hill DF, Moholt-Siebert M (1990) Involvement of transforming growth factor $\alpha$ in the release of luteinizing hormone-releasing hormone from the developing female hypothalamus. Proc Natl Acad Sci USA 87:9698-9702.

Pascall JC, Brown KD (1988) Structural analysis of the 5'-flanking sequence of the mouse epidermal growth factor gene. J Mol Endocrinol 1:5-11.

Perheentupa J, Lakshmanan J, Hoath SB, Beri U, Kim H, Macaso T, Fisher DA (1985a) Epidermal growth factor measurements in mouse plasma: method, ontogeny, and sex difference. Am J Physiol 248: E391-E396

Perheentupa J, Lakshmanan J, Fisher DA (1985b) Urine and kidney epidermal growth factor: ontogeny and sex difference in the mouse. Pediatr Res 19:428-432.

Pfeffer S, Ullrich A (1985) Epidermal growth factor. Is the precursor a receptor? Nature 313:184.

Popliker M, Shatz A, Avivi A, Ullrich A, Schlessinger J, Webb CG (1987) Onset of endogenous synthesis of epidermal growth factor in neonatal mice. Dev Biol 119:38-44.

Poulsen SS, Nexo E, Skov Olsen P, Hess J, Kirkegaard P (1986) Immunohistochemical localization of epidermal growth factor in rat and man. Histochemistry 85:389-394.
Probstmeier R, Schachner M (1986) Epidermal growth factor is not detectable in developing and adult rodent brain by a sensitive doublesite enzyme immunoassay. Neurosci Lett 63:290-294.

Proper JA, Moses HL (1981) Detection of transforming growth factor in mouse embryos. J Supramol Struct 5:235.

Rall LB, Scott J, Bell GI, Crawford RJ, Penschow JD, Niall HD, Coghlan JP (1985) Mouse prepro-epidermal growth factor synthesis by the kidney and other tissues. Nature 313:228-231.

Reynolds BA, Tetzlaff W, Weiss S (1990) EGF-and TGF- $\alpha$-responsive striatal embryonic progenitor cells produce both neurons and astrocytes. Soc Neurosci Abstr 16:1147.

Sambrook J, Fritsch EF, Maniatis T (1989) Molecular cloning. A laboratory manual. Cold Spring Harbor, NY: Cold Spring Harbor Laboratory.

Samsoondar J, Kobrin MS, Kudlow JE (1986) $\alpha$-Transforming growth factor secreted by untransformed bovine anterior pituitary cells in culture. I. Purification from conditioned medium. J Biol Chem 261: 14408-14413.

Schaudies RP, Christian EL, Savage CR (1989) Epidermal growth factor immunoreactive material in the rat brain. Localization and identification of multiple species. J Biol Chem 264:10447-10450.

Schreiber AB, Winkler ME, Derynck R (1986) Transforming growth factor- $\alpha$ : a more potent angiogenic mediator than epidermal growth factor. Science 232:1250-1252.

Scott J, Urdea M, Quiroga M, Sanchez-Pescador R, Fong N, Selby M, Rutter WJ, Bell GI (1983) Structure of a mouse submaxillary messenger RNA encoding epidermal growth factor and seven related proteins. Science 221:236-240.

Shelton DL, Reichardt LF (1986) Studies on the expression of the $\beta$ nerve growth factor (NGF) gene in the central nervous system: level and regional distribution of NGF mRNA suggest that NGF functions as a trophic factor for several distinct populations of neurons. Proc Natl Acad Sci USA 83:2714-2718.

Simpson DL, Morrison R, De Vellis J, Herschman HR (1982) Epidermal growth factor binding and mitogenic activity on purified populations of cells from the central nervous system. J Neurosci Res 8: 453-462.

Twardzik DR (1985) Differential expression of transforming growth factor $\alpha$ during prenatal development of the mouse. Cancer Res 45: 5413-5416.

Velkeniers B, Hooghe-Peters EL, Hooghe R, Belayew A, Smets G, Claeys A, Robberecht P, Vanhaelst L (1988) Prolactin cell subpopulations separated on discontinuous percoll gradient: an immunocytochemical, biochemical, and physiological characterization. Endocrinology 123:1619-1630.

Werner MH, Nanney LB, Stoscheck CM, King LE (1988) Localization of immunoreactive epidermal growth factor receptors in human nervous system. J Histochem Cytochem 36:81-86.

Wilcox JN, Derynck R (1988) Localization of cells synthesizing transforming growth factor-alpha mRNA in the mouse brain. J Neurosci 8:1901-1904.

Winkler ME, O'Connor L, Winget M, Fendly B (1989) Epidermal growth factor and transforming growth factor $\alpha$ bind differently to the epidermal growth factor receptor. Biochemistry 28:6373-6378.

Wong ST, Winchell LF, McCune BK, Earp HS, Teixidó J, Massagué J, Herman B, Lee DC (1989) The TGF- $\alpha$ precursor expressed on the cell surface binds to the EGF receptor on adjacent cells, leading to signal transduction. Cell 56:495-506. 